Keywords: Tank Farm Characterization Corrosion, Enrichment, Cross-check analysis Evaporator Feed

Qualification

Retention: Permanent

\title{
Tank 30 and 37 Supernatant Sample Cross-check and Evaporator Feed Qualification Analysis -2012
}

L. N. Oji

March, 2013

Savannah River National Laboratory Savannah River Nuclear Solutions, LLC Aiken, SC 29808

Prepared for the U.S. Department of Energy under contract number DE-AC09-08SR22470. 


\section{DISCLAIMER}

This work was prepared under an agreement with and funded by the U.S. Government. Neither the U.S. Government or its employees, nor any of its contractors, subcontractors or their employees, makes any express or implied:

1. warranty or assumes any legal liability for the accuracy, completeness, or for the use or results of such use of any information, product, or process disclosed; or

2. representation that such use or results of such use would not infringe privately owned rights; or

3. endorsement or recommendation of any specifically identified commercial product, process, or service.

Any views and opinions of authors expressed in this work do not necessarily state or reflect those of the United States Government, or its contractors, or subcontractors.

\section{Printed in the United States of America}

Prepared for

U.S. Department of Energy 


\section{REVIEWS AND APPROVALS}

\section{AUTHORS:}

L N. Oji, Advanced Characterization \& Processing

Date

\section{TECHNICAL REVIEW:}

M. S. Hay, Advanced Characterization \& Processing

Date

\section{APPROVAL:}

F. M. Pennebaker, Manager

Date

Advanced Characterization \& Processing

S. L. Marra, Manager

Date

Environmental \& Chemical Process Technology Research Programs

K. E. Cheeks, F/H Laboratory

Date

L. H. Connelly, Analytical Development

Date

C. E. Duffey, TF Engineering

Date SRR

D. J. Martin, TF Engineering

Date SRR 


\section{EXECUTIVE SUMMARY}

This report summarizes the analytical data reported by the F/H and Savannah River National Laboratories for the 2012 cross-check analysis for high level waste supernatant liquid samples from SRS Tanks 30 and 37. The intent of this Tank 30 and 37 sample analyses was to perform cross-checks against routine $\mathrm{F} / \mathrm{H}$ Laboratory analyses (corrosion and evaporator feed qualification programs) using samples collected at the same time from both tanks as well as split samples from the tanks.

Of the eight Tank 30 and 37 samples pulled, two were pulled at the surface of each tank and two others were variable depth samples (Tank 30 pulled from 218 inches and Tank 37 pulled from 340 inches) from each tank. Four of these samples were delivered to SRNL and the other four samples were delivered to $\mathrm{F} / \mathrm{H}$ Laboratory for characterization and eventual compilation of the data to compare and identify inconsistencies in the analytical results for routine high level waste tank supernate characterization by the two laboratories. These Tanks 30 and 37 samples sent to each laboratory constitute two sets of data; one set from each laboratory. A third set of data, derived from splitting the SRNL sample set into nearly two nearly equal parts, was sent to $\mathrm{F} / \mathrm{H}$ Laboratory. In all, three sets of Tanks 30 and 37 supernatant liquid samples were analyzed by both laboratories (One half split-sample set from SRNL and two sets from F/H Laboratory) for this cross-check evaluation.

In these analyses, a 20 percent relative deviation was used as the benchmark for measuring the relative difference between the laboratory results for the same component analysis by the two laboratories. Data for the same component analysis from the two laboratories which differed by more than 20 percent relative deviation was considered as not comparable or not in agreement.

In general, the two laboratories were able to produce analytical results for the following components: free-OH, nitrate, nitrite, oxalate, cesium-137, and specific gravity, which were fairly comparable if not considered identical in magnitude in most cases. Unlike in previous crosscheck evaluations (2008) the free-OH concentrations obtained at two different acid titration concentrations ( $0.1 \mathrm{~N}$ and $0.01 \mathrm{~N}$ acid titrants) by the two laboratories were quite comparable $88 \%$ of the time the analyses was performed. The percent relative deviation between the analytical results of the two laboratories for free-OH averaged less than $20 \%$.

On the other hand, the analytical results from both laboratories for carbonates, silicon, sulfate, chloride and phosphates in all three sets of Tank 30 and 37 results from the two laboratories were greater than the 20 percent relative deviation benchmark and methods/analytical techniques will need to be evaluated further by both laboratories to determine the cause of such significant differences in analytical results between the two laboratories. The high sodium concentrations in the original Tanks 30 and 37 samples (averaging 15M) means that a significant dilution of the original sample is required to minimize the impact of high alkali content on analytical instruments performance (for example ICP-ES plasma and IC performance). These large dilutions of the original samples lead to anion and cation concentrations (sulfate, phosphate, silicon and chloride) which are too close to instrument detection limits for these analytes and thus introduce significant errors in measurements.

The inability of the two laboratories to get good agreement in the analyses for carbonate may not only be attributable to dilution effects and the use of different analytical methods, as described, but also to the fact that it is difficult to get reliable analytical values for low carbonate samples in the presence of $15 \mathrm{M}$ sodium hydroxide. 
This along with heating of Tanks 30 and 37 samples by F/H Laboratory to match the tank temperatures prior to sampling for analyses may lead to different analytical results when compared to the SRNL-AD results for these components of Tanks 30 and 37. SRNL-AD did not heat the samples. However, it is worth noting that the SRNL-AD reagent or matrix blanks and cell blanks for silicon were high. So, there may be some silicon contamination issues which SRNL-AD need to address.

The large measures of relative differences between the two laboratory results for these anions and cations were also observed in some of the 2008 cross-check measurements.

Based on discussions with the liquid waste customer, none of these results present a significant concern in the current measurement of process samples or the Tank Farm. The measurement of carbonate and anions such as sulfate, phosphate, and chlorides are performed to evaluate impacts in the ionic strength of the samples. If the carbonate and other anions are low, their impact on the ionic strength would be negligible. Also, while silicon is low for these samples, typical measurements at SRNL are performed on the $2 \mathrm{H}$ evaporator tanks, which have higher concentration of silicon, which minimizes the impact of the silicon in the blank.

Recommendation to enhance the goals of cross-check comparisons between the two laboratories includes the following:

- Both laboratories (SRNL-AD and F/H laboratories) should work on method improvements to enhance analyzes for both silicon and carbonate at low concentrations.

- Although it is non-routine for SRNL-AD group to heat tank samples to specific tank temperature prior to analysis for cations and anions, it will be useful for the sake of these types of comparative analyses between the two laboratories for SRNL-AD to heat the samples to the same temperature that $\mathrm{F} / \mathrm{H}$ laboratory treats the samples prior to analysis. This temperature treatment will eliminate the problems associated with changes in sample density, precipitation and uneven sample pipetting and deliveries

- If possible, both laboratories should employ the same analytical methods in all these analyses. 


\section{TABLE OF CONTENTS}

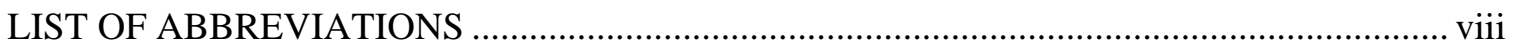

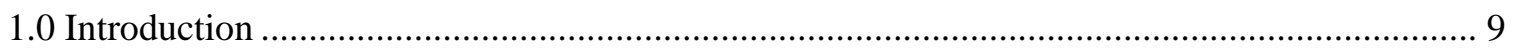

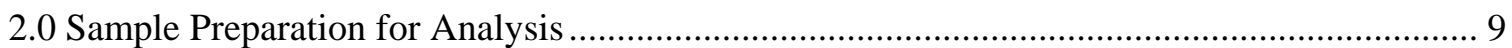

3.0 Results of Analyses of Tanks 30 and 37 Supernatant Samples........................................... 11

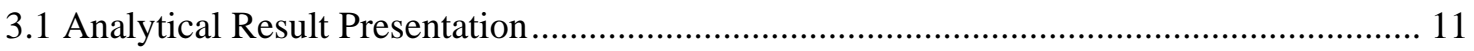

3.2 Tank 30 and 37 Sample Comparisons: Surface and Variable Depth Samples Acquired at the

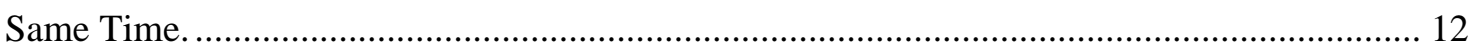

3.3 Tank 30 and 37 Sample Comparisons: Split Surface and Variable Depth Samples............ 13

3.4 Overall Analysis Performance comparison for the Analytes by the two Laboratories........ 14

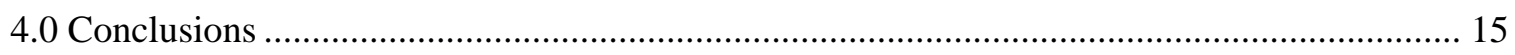

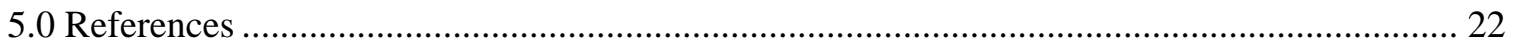

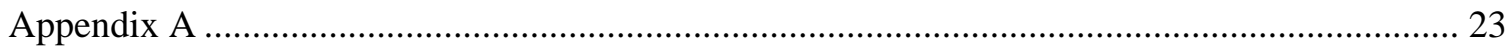

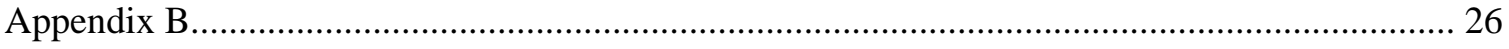

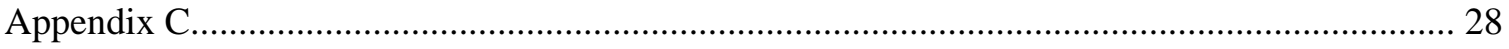




\section{LIST OF TABLES}

Table 1 Tanks 30 and 37 supernate samples pulled and delivered to the two laboratories. 9

Table 2 Cross Check Analysis: Tank 30 Analyses: SRNL and F/H Laboratory Average Result Values Compared-Surface and Variable depth Samples@

Table 3 Cross Check Analysis: Tank 37 Analyses: SRNL and F/H Laboratory Average Result Values Compared-Surface and Variable depth Samples. 18

Table 4 Cross Check Analysis: Tank 30 Analyses: SRNL and F/H (SPLIT Sample) Laboratory Results Compared-Surface and Variable depth Samples.

Table 5 Cross Check Analysis: Tank 37 Analyses: SRNL and F/H (SPLIT Sample) Laboratory Results Compared-Surface and Variable depth Samples.

Table 6 Summary of Analytical comparisons between the two laboratories for analytical

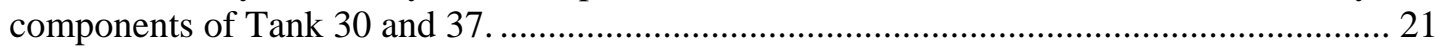

Table 7.Cross Check Analysis for Tanks 30 Samples-Duplicate SRNL analysis: Tank 30 Surface and Variable Depth

Table 8 Cross Check Analysis for Tanks 37 Samples-Duplicate SRNL analysis Tank 37 Surface

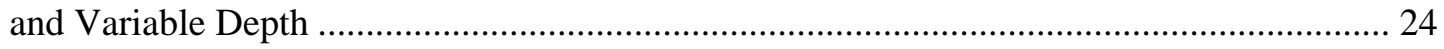

Table 9. Check Analysis for Tanks 30 Samples- F/H analysis Tank 30 Surface and Variable Depth. 25

Table 10. Cross Check Analysis for Tanks 37 Samples- F/H analysis Tank 37 Surface and Variable Depth

Table 11. Cross Check Analysis for Tanks 30 Samples-Duplicate analysis-F/H-SPLIT SAMPLE 26

Table 12. Cross Check Analysis for Tank 37 Samples-Duplicate analysis F/H-SPLIT SAMPLE. - 
SRNL-STI-2012-00550 Rev. 0

\section{LIST OF ABBREVIATIONS}

$\begin{array}{ll}\text { AD } & \text { Analytical Development } \\ \text { CC } & \text { Corrosion Control } \\ \text { CC/ EFQ } & \text { Corrosion Control/Evaporator Feed Qualification } \\ \text { EFQ } & \text { Evaporator Feed Qualification } \\ \text { ICP-ES } & \text { Inductively Coupled Plasma-Atomic Emission Spectroscopy } \\ \text { ICP-MS } & \text { Inductively Coupled Plasma-Mass Spectroscopy } \\ \text { LIMS } & \text { Laboratory Information Management System } \\ \text { LWO } & \text { Liquid Waste Operations } \\ \text { MDA } & \text { Minimum Detectable Activity: Minimum detectable activity is the value } \\ \text { SpG } & \text { above which instrument signal can be considered real. } \\ \text { SRNL-AD } & \text { Specific Gravity } \\ \text { SRNL } & \text { Savannah River National Laboratory-Analytical Development } \\ \text { SRR } & \text { Savannah River National Laboratory } \\ \text { TIC/TOC } & \text { Total inorganic carbon/Total organic carbon } \\ \text { TTQAP } & \text { Task Technical Quality Assurance Plan } \\ \text { TTR } & \text { Technical Task Request } \\ \text { VDS } & \text { Variable Depth Sample }\end{array}$




\subsection{Introduction}

Liquid Waste Processing Engineering personnel requested cross-check analyses of $\mathrm{F} / \mathrm{H}$ Laboratory sample results for Tank 30 and 37 supernate samples. The intent of this analysis was to compare the analysis results from both SRNL and F/H Laboratories for given tank farm sample components as specified by SRR. These characterizations by both laboratories also includes analyses for evaporator feed qualification. Overall, this task examined Evaporator Feed Qualification (EFQ) and Corrosion Control (CC) parameters of surface and variable depth samples (VDS) pulled from Tanks 30 and 37.

A total of eight samples were pulled from Tanks 30 and 37. Of these samples, two were pulled at the surface of each tank and two others were VDS from each tank. Four of these samples were delivered to SRNL and the other four samples were delivered to F/H Laboratories as summarized in Table 1 below.

Table 1 Tanks 30 and 37 supernate samples pulled and delivered to the two laboratories.

\begin{tabular}{|l|c|c|c|}
\hline Sample ID & Sampling location & Sample Destination & Analyses category \\
\hline HTF-30-12-1 & surface & F/H & CC/EFQ \\
\hline HTF-30-12-2 & 218 inches & F/H & EFQ \\
\hline HTF-37-12-4 & surface & F/H & CC/EFQ \\
\hline HTF-37-12-5 & 340 inches & F/H & EFQ \\
\hline & & & CC/EFQ \\
\hline HTF-30-12-6 & surface & SRNL & EFQ \\
\hline HTF-30-12-7 & 218 inches & SRNL & CC/EFQ \\
\hline HTF-37-12-8 & surface & SRNL & EFQ \\
\hline HTF-37-12-9 & 340 inches & SRNL & \\
\hline
\end{tabular}

where:

$\mathrm{CC} / \mathrm{EFQ}=\mathrm{SpG}$, nitrate, nitrite, free hydroxide, total gamma (from Cs-137), sulfate, phosphate, oxalate, carbonate, sodium, aluminum, silicon

$\mathrm{EFQ}=\mathrm{SpG}$, free hydroxide, sulfate, phosphate, oxalate, carbonate, sodium, aluminum, silicon.

In this report an attempt has been made to compare and identify inconsistencies in the analytical results for routine high level waste tank supernate characterization by the two laboratories. Samples from these two tanks were analyzed in accordance with Technical Task Request (TTR) ${ }^{1}$ and the Task Technical and Quality Assurance Plan (TTQAP ${ }^{2}$ ).

\subsection{Sample Preparation for Analysis}

After opening the four samples assigned to SRNL (HTF-30-12-6, HTF-30-12-7, HTF-37-12-8, HTF-37-12-9), SRNL and F/H Laboratory personnel visually examined the four samples for the existence of solid particles and clarity. The supernate samples seemed fairly clear although with some cloudiness. There were no visible solid particles. However, during transfer of one of the samples from the original steel container (HTF-37-12-8) to a clear poly-methyl pentane secondary container for visual observation with the use of small plastic funnel a small piece of solid salt cake was seen lodged in the funnel vertical transfer duct. This particular sample was then decanted to remove the small salt cake. In accordance with cross-check analyses recommendations from the 2008 cross-check comparisons ${ }^{3}$ one half of the split sample unit in labeled stainless steel sample holders was sent to $\mathrm{F} / \mathrm{H}$ Laboratory for characterization, while SRNL analyzed the other half of the sample set with original sample labels (HTF-30-12-6, HTF- 
30-12-7, HTF-37-12-8, HTF-37-12-9). The portion of the four samples sent to F/H Laboratory were sent in labeled 80-mL capacity stainless steel sample holders (HTF-30-12-6-F/H, HTF-3012-7-F/H, HTF-37-12-8-F/H and HTF-37-12-9-F/H).

In these cross-check analyses, both $\mathrm{F} / \mathrm{H}$ and SRNL laboratories were required to perform separate sample preparations (duplicate sample preparations) and not rely merely on duplicate measurements of the same sample. F/H Laboratory performed their analyses as usual, meaning, bringing the sample temperature to a given temperature of the tank under consideration. SRNL was not required to heat the sample to mimic $\mathrm{F} / \mathrm{H}$ procedures, but was required to document shielded cell temperatures during sample preparations as mentioned above. Titration of the samples for free-OH was based on 0.1 M HCL titrant for SRNL and 0.01 M HCL titrant for F/H Laboratory. Both laboratories analyzed for silicon via warm acid strike followed by ICP-ES analysis for silicon. With the exception of F/H Laboratory analyses results for the un-split Tank 30 and 37 samples, all samples were analyzed and reported in duplicate by both laboratories.

These Tank 30 and Tank 37 samples respectively, surface samples HTF-30-12-1 and HTF-37-124 and variable depth samples (HTF-30-12-2 and HTF-37-12-5) were analyzed by F/H Laboratory only once for each analyte.

Components analyzed for in these supernate samples included free- $\mathrm{OH}^{-1}, \mathrm{NO}_{2}{ }^{-1}, \mathrm{NO}_{3}{ }^{-1}, \mathrm{SO}_{4}{ }^{-2}$, $\mathrm{CO}_{3}^{-2}, \mathrm{C}_{2} \mathrm{O}_{4}{ }^{-2}, \mathrm{PO}_{4}^{-3}, \mathrm{Al}, \mathrm{Si}, \mathrm{Na}$, total gamma, and specific gravity.

The SRNL sample sets were prepared in the shielded cell and submitted to SRNL Analytical Development (AD) for the required analyses. The sample preparation, which involved a target sample dilution factor by volume of $25 \pm 1$ of Tank $30 \mathrm{H}$ and $37 \mathrm{H}$ supernatant liqueurs with deionized water, were accomplished in the SRNL shielded cells prior to submittal to the SRNL Analytical Development for the required analyses. The shielded cell temperature reading during the initial opening of the sample was $19{ }^{\circ} \mathrm{C}$. During the entire samples processing (Sample opening, decanting, 50/50 partitioning of the samples to be delivered to $\mathrm{F} / \mathrm{H}$ Laboratory and diluting of samples to take out of the cell) five cell temperature measurements were taken and these ranged from $19.0^{\circ} \mathrm{C}$ to $22.2^{\circ} \mathrm{C}$ with an average of $20.2 \pm 1.3^{\circ} \mathrm{C}$.

Analytical methods employed in these characterizations include atomic absorption (AA) for $\mathrm{Na}$ analysis and inductively coupled plasma-emission spectroscopy (ICP-ES) for Si (warm acid strike before ICP-ES) and Al. AD used ion chromatography (IC) to measure several of the anions $\left(\mathrm{NO}_{2}{ }^{-1}, \mathrm{NO}_{3}{ }^{-1} \mathrm{SO}_{4}{ }^{-2}, \mathrm{C}_{2} \mathrm{O}_{4}{ }^{-2}\right.$ and $\left.\mathrm{PO}_{4}{ }^{-3}\right)$. A titration method was used for free hydroxide and carbonate analysis. SRNL-AD analyzed for carbonate by total inorganic carbon while $\mathrm{F} / \mathrm{H}$ Laboratory analyzed for carbonate by titration method.

For this peer reviewed technical report, two sets of Tank 30 and 37 sample characterization data were obtained from $\mathrm{F} / \mathrm{H}$ Laboratory. The first set from $\mathrm{F} / \mathrm{H}$ Laboratory was the split Tanks 30 and 37 sample portions [HTF-30-12-6-F/H, HTF-30-12-7-F/H, HTF-37-12-8-F/H and HTF-37$12-9-\mathrm{F} / \mathrm{H}]$ provided by SRNL for analyses and the second set were original Tank 30 and 37 samples [HTF-30-12-1, HTF-30-12-2, HTF-37-12-4 and HTF-37-12-5] directly assigned to F/H Laboratory by SRR for characterization. The third sample set, which is part of the split sample from Tanks 30 and 37, were prepared and characterized by SRNL. The cross-check analytical data comparison between the two laboratories are therefore based on component analyses results from these three sets of Tank 30 and 37 samples described above. 


\subsection{Results of Analyses of Tanks 30 and 37 Supernatant Samples}

The intent of this Tank 30 and 37 characterizations was to perform cross-checks against routine F/H Laboratory analyses (corrosion and evaporator feed qualification programs) using samples collected at the same time from both tanks as well as split samples from the tanks. An attempt has been made to compare and identify inconsistencies in the analytical results for routine high level waste tank supernate characterization by $\mathrm{F} / \mathrm{H}$ and SRNL laboratories.

The Tanks 30 and 37 samples (as-received) were almost clear supernatant liqueurs as expected. A visual inspection of the samples showed that each sample was a cloudy solution with no visible suspended fine particles. Components/parameters analyzed for in these Tank 30 and 37 supernatant samples included free $\mathrm{OH}^{-1}, \mathrm{NO}_{2}^{-1}, \mathrm{NO}_{3}^{-1}, \mathrm{SO}_{4}^{-2}, \mathrm{CO}_{3}^{-2}, \mathrm{C}_{2} \mathrm{O}_{4}{ }^{-2}, \mathrm{PO}_{4}^{-3}, \mathrm{Al}, \mathrm{Si}, \mathrm{Na}$, total gamma scan for Cs-137, and specific gravity.

In all, three sets of Tank 30 and 37 component analytical results from both laboratories have been compiled and compared; two sets of Tank 30 and 37 analytical data from F/H Laboratory and one set from SRNL.

With the exception of one set of F/H Laboratory analyses for Tanks 30 and 37, all analytical results were performed by the two laboratories in duplicate. Silicon and free-OH analysis were performed in triplicate and in the case of free- $\mathrm{OH}$ acid titrations were performed at two acid concentrations levels, 0.1 and $0.01 \mathrm{M}$, by SRNL and F/H Laboratory, respectively. In cases where one or both of the results are below the limit of detection no standard deviation is given. For species where the concentration fell below the lower limit of detection the reported lower limit of detection is preceded by "<”.

In this report, analyses results from both laboratories for a component is flagged when the percent relative deviation, a measure of the relative difference between the laboratory results for the same component analysis, is more than $20 \%$.

The $\mathrm{pH}$ results presented in the tables were calculated from the average free- $\mathrm{OH}^{-}$concentrations based on the 0.1 and $0.01 \mathrm{M}$ acid titrations for the two tank samples using the following equation:

$$
p H=14+\log _{10}\left(O H^{-}\right)
$$

\subsection{Analytical Result Presentation}

The average analytical results reported by the two laboratories for all the analytes of interest are presented in Tables 2 through Table 5, respectively, for Tank 30 surface and variable depth samples, Tank 37 surface and variable depth samples, Tank 30 split sample (surface and variable depth) and Tank 37 split sample (surface and variable depth). Each table also contains the calculated percent relative deviations (\%RD) for the corresponding surface and variable depth samples data information from both laboratories.

Replicate data are presented in Appendices A and B. Appendix C contains the SRNL Analytical Development Tracking numbers (Laboratory Information Management System number) for all Tanks 30 and 37 sample analyses. Blank spaces within the tables followed by a dash are used to indicate those cases where a particular analyte was not measured by a laboratory. The percent relative deviation (\%RD) is used as a measure of the relative difference between the laboratory 
results for the same analysis. Percent relative deviation was calculated as the difference between the result from two data sets for the same analyte from the two laboratories divided by the mean*100, as shown below.

$((\mathrm{A}-\mathrm{B}) /(\mathrm{A}+\mathrm{B}) / 2) * 100$.

Where: A and B represent magnitude of analysis result for the same analyte by the two laboratories.

For the purpose of this evaluation and comparison, a \% relative deviation of $20 \%$ was chosen as the criterion for determining if the results from the two laboratories were considered comparable or in agreement. Percent relative deviations values were not calculated for analytical results below detection limits. Percent relative deviations values less than or equal to $20 \%$ indicate the analytical data from the two laboratories or replicates are considered to be in reasonable agreement.

3.2 Tank 30 and 37 Sample Comparisons: Surface and Variable Depth Samples Acquired at the Same Time.

As described earlier and presented in Table 1, two surface and two variable depth samples from Tanks 30 and 37 (218 and 340 inches, respectively) were collected and delivered to both laboratories for characterization for given analytes as shown in Tables 2 and 3. Since these samples were pulled at the same time and from the same tank levels, one would expect the concentration of the analytes from both laboratories to be same using the similar analytical techniques.

However, based on the average values summarized in Table 2 for the surface and variable depth samples from Tank 30, the percent relative deviations (\%RD) calculated from the analytical result data presented by the two laboratories shows that the results are not comparable for a few of the analytes. In order words, the $20 \% \mathrm{RD}$ evaluation criterion was not met in component analytical results by the two laboratories for aluminum, sulfate, carbonate, sodium and silicon ions. For the Tank 30 surface sample, the percent relative deviations between the two laboratory analytical results for these analytes (aluminum, sulfate, carbonate, sodium and silicon ions) varied from $39 \%$ to $74 \%$. In the variable depth Tank 30 samples these \%RD values for aluminum, sulfate, carbonate, sodium and silicon ions varied from $31 \%$ to $107 \%$. These percent relative deviations are all well above the $20 \% \mathrm{RD}$ criterion.

Free-OH concentration measurements by the two laboratories were comparable in almost all the analyses results for this analyte. Analysis result for free-OH in the variable Tank 30 sample by the two laboratories, at $29 \%$ percent relative deviation, was the only instance when the percent relative deviation was outside the $20 \%$ bench mark for free-OH analyses by the two laboratories.

The analytical results presented by the two laboratories for Tank 30 surface samples for specific gravity, nitrite, nitrate, free-OH and cesium-137 concentration are all less than $15 \% \mathrm{RD}$ and thus are considered comparable. Tank 30 surface sample result for phosphate by the two laboratories at $19.1 \% \mathrm{RD}$ is just on the border line in terms of meeting the $20 \% \mathrm{RD}$ criterion for acceptability.

F/H Laboratory did not analyze for chloride in the Tank 30 surface and variable samples and also did not analyze for nitrate, nitrite, and cesium-137 in the variable depth Tank 30 samples. The percent relative deviation for specific gravity and phosphate analyses for the Tank 30 variable depth samples components by the two laboratories are considered comparable at percent relative deviations of 0.43 and 9.88 , respectively. 
Overall, the two laboratories failed to obtain comparable analytical results in the analyses for anion (sulfate, carbonate) and cations (aluminum, sodium and silicon) in both surface and variable depth samples from Tank 30.

In Tank 37 surface and variable depth analyses results for the components presented in Table 3, both laboratories met the expected analytical results for specific gravity, aluminum, phosphate and free-OH concentrations. The \%RD for these analytes averaged below 10\%. The Tank 37 surface sample analyses results for sodium was just below the criteria for acceptability at $19.4 \%$ RD. Nitrite ion concentrations measured by both laboratories in the Tank 37 surface sample at $21.9 \% \mathrm{RD}$ were just above the acceptability requirement.

Tank 37 surface and variable depth sample analyses result by both laboratories for carbonate and silicon were not comparable at all. The percent relative deviation calculated from data provided from both laboratories for both variable and surface samples for carbonate averaged above $118 \%$, while that for silicon averaged above $50 \%$. Thus, analysis results for these two anions by both laboratories failed the $20 \% \mathrm{RD}$ criterion for acceptability. Sodium analyses in the variable depth Tank 37 sample by these two laboratories are not also comparable at 25.9 \%RD.

F/H Laboratory did not analyze for chloride in both Tank 37 variable depth and surface samples. F/H Laboratory did not also analyze for nitrate, nitrites and cesium-137 in the Tank 37 variable depth sample.

\subsection{Tank 30 and 37 Sample Comparisons: Split Surface and Variable Depth Samples}

The Tank 30 and 37 samples (both surface and variable depth sample) sent to SRNL was split into two nearly equal portions and one half of each split sample unit was sent to F/H Laboratory for characterization, while SRNL analyzed the other halves. As noted in the experimental section, one of the SRNL samples which was split into two equal portions contained visible solid saltcake (Sample HTF-37-12-8). Everything being equal, one would expect the concentration of the analytes from both laboratories to be equivalent.

Characterization results from the two laboratories for Tank 30 split samples (surface and variable depth) for specific gravity, nitrate, nitrite, aluminum, sodium and free-OH are comparable because the calculated percent relative deviation between the results from the two laboratories do not differ by more than 20\%; see Table 4 . Analyses results for sulfate, silicon and chloride for both surface and variable depth Tank 30 split samples from both laboratories differ by more than 20\% and are 54.3\% (surface sulfate), 75.3\% (VDS sulfate), 63.4\% (surface silicon), and $96.2 \%$ VDS silicon). The analyses results by the two laboratories for Tank 30 split sample, for carbonate in the surface sample were comparable because the \%RD was just under $10 \%$ at $9.35 \%$. However, the variable depth analyses result by the two laboratories for the Tank 30 split sample for carbonate anion did not compare favorably because the \%RD was $45.8 \%$. Phosphate analyses results for split Tank 30 samples at percent relative deviations of $32 \%$ for the surface sample and $36.4 \%$ for the variable depth sample do not compare favorably between the two laboratories.

F/H Laboratory did not analyze for cesium-137 in the Tank 30 split variable depth sample. However, F/H Laboratory analyses result for cesium-137 in the Tank 30 split surface sample is comparable with the corresponding analyses result by SRNL at \%RD of $1.13 \%$.

Table 5 contains the Tank 37 split samples average analytical results from the two laboratories. Analytical results for Tank 37 split samples (surface and variable depth) from the two laboratories 
differ by less than $20 \%$ for the following measurements specific gravity, nitrate, nitrite, sodium and free-OH. Hence, these analytical results for the laboratories are comparable. Aluminum analyses in the surface samples by both laboratories have a $20.2 \% \mathrm{RD}$, which makes it a borderline case in terms of being comparable. However, both the surface and variable depth analyses results from the two laboratories on carbonate, phosphate, silicon and chloride differ by $>20 \% \mathrm{RD}$, and thus are not comparable. F/H Laboratory did not analyze for cesium-137 in the Tank 37 split variable depth sample. However, F/H Laboratory analyses result for cesium-137 in the Tank 37 split surface sample is comparable with the corresponding analyses result by SRNL at $\% \mathrm{RD}$ of $3.92 \%$.

Again in this split Tank 37 sample, mostly the anions (carbonate, phosphate and chloride) and silicon were not comparable in the analytical results presented by the two laboratories.

\subsection{Overall Analysis Performance comparison for the Analytes by the two Laboratories.}

Table 6 shows a summary of the number of times, in percent, a given analyte analyzed by both laboratories failed to meet the minimum $20 \% \mathrm{RD}$ difference criterion between the two laboratory results for that analyte.

With the analysis result for free-OH in Tank 30 variable depth samples and for nitrite in Tank 37 surface samples being the exceptions, the analyses by both laboratories for specific gravity, free$\mathrm{OH}$, nitrate, nitrite, cesium 137, and possible oxalate anion all met the $20 \% \mathrm{RD}$ difference criterion. This means that the analytical data from the two laboratories (SRNL and $\mathrm{F} / \mathrm{H}$ ) are considered to be in a reasonable agreement. It should be noted that these samples were fairly high in hydroxide, which may have enabled easier measurements than previous cross-check characterizations. Free-OH analyses result by both laboratories for variable depth Tank 30 samples has a \%RD of 28.6, while nitrite analyses in Tank 37 surface samples has a \%RD of 21.9. These \%RD for free-OH and nitrite are above the $20 \% \mathrm{RD}$ benchmark. Since the analyses result for oxalate ion by both laboratories are all less than values the assumption here is that the $20 \%$ $\mathrm{RD}$ criterion was met.

In general, species at higher concentrations (0.1 $\mathrm{M}$ or higher) compared fairly well between the labs on split samples from SRNL. This may indicate that some of the measurement issues may be related to either sampling, solids in the sample or sample preparation.

The high sodium concentration in the original Tanks 30 and 37 samples (averaging 15M) means that a significant dilution of the original sample to minimize the impact of high alkali content on analytical instruments performance (for example ICP-ES plasma and IC performance) is required. In the case of silicon for example, the required dilution leads to a $\mathrm{Na} / \mathrm{Si}$ ratio in the order of 8500:1 on $\mathrm{mg} / \mathrm{L}$ basis. This large dilution of the original samples leads to anion and cation concentrations (sulfate, phosphate, silicon and chloride) which fall close to instrument detection limits for certain analytes and thus impacts biases in measurements. Fifty percent of the time the comparative analyses result for both sulfate and phosphate anions met the $20 \% \mathrm{RD}$ criterion when they were analyzed by both laboratories.

In the case where elements were measured at higher concentrations for similar instrumentation (sodium or nitrate) on split samples, the results tended to be more comparable.

However, it is worth noting that the SRNL-AD reagent or matrix blanks and cell blanks for silicon had a measureable bias at 8.52 and $10.3 \mathrm{mg} / \mathrm{L}$ silicon, respectively. This is likely the reason for the discrepancy in silicon measurements between the two laboratories. However, the 
silicon concentration in these samples was fairly low compared to concentrations that would initiate formation of sodium aluminum silicate solids. This bias at this time would have minimal impact at these concentrations. However, these contamination issues should be reviewed to minimize or eliminate trace silicon.

Carbonate analyses results failed in all cases but in the Tank 30 surface sample split. In some instances, as in the case with carbonate anion, the analysis difference was sometimes even greater than $100 \%$. It is worth noting that SRNL analyzed for carbonate and silicon eight different times, while $\mathrm{F} / \mathrm{H}$ Laboratories analyzed for these components six and eight times, respectively. The laboratories used different methods to analyze for carbonate. In F/H Laboratory, carbonate was measured by precipitation of carbonate followed by titration. With the high concentration of hydroxide in these samples, washing of the residual solids may not have been sufficient. With the lower concentration of carbonate in these samples, residual hydroxide would potentially bias the titration measurements. However, carbonate and most of the other low concentration anions are primarily measured in the Tank Farm to determine the impact of ionic strength. In each of these cases, the low concentration of the anion will have a negligible impact on the ionic strength.

\subsection{Conclusions and Recommendations}

In these Tanks 30 and 37 cross-check sample characterizations, results from both laboratories for components were flagged when the percent relative deviation, a measure of the relative difference between the laboratory results for the same component analysis, was more than $20 \%$. In general, the two laboratories were able to produce analytical results for the following components free- $\mathrm{OH}$, nitrate, nitrite, oxalate cesium-137and specific gravity, which were fairly comparable if not considered identical in magnitude in most cases. Unlike in previous cross-check evaluations $(2008)^{3}$ the free-OH concentrations obtained at two different acid titration concentrations $(0.1 \mathrm{~N}$ and $0.01 \mathrm{~N}$ acid titrants) by the two laboratories were quite comparable in about $88 \%$ of the time the analyses was performed. The percent relative deviation between the analyses results of the two laboratories for free-OH averaged less than $20 \%$.

On the other hand, the analytical results from both laboratories for carbonates, silicon, sulfate, chloride and phosphates in all three sets of data from the two laboratories fall outside of the 20 percent relative deviation benchmark and can be evaluated further by both laboratories to determine the root cause of such significant differences in analytical results between the two laboratories.

Evaluation of the analytical results from the split sample set also showed that analysis for sulfate, silicon, chloride, carbonates and phosphates from both laboratories were not comparable. For example, in the split Tank 30 samples the percent relative deviations for sulfate, silicon and chloride averaged greater than 65, 80, and $27 \%$, respectively.. Similarly, for the split Tank 37 samples the percent relative deviations between the two laboratories in the analysis for carbonate, phosphate, silicon and chloride averaged greater than $30,37,59$, and $42 \%$, respectively. This is likely the result of a significant dilution to levels close to the detection limits for most of these species and low level silicon contamination in the sample preparation.

The inability of the two laboratories to get good agreement in the analyses for carbonate may not only be attributable to dilution effects, as described above, but also to the fact that it is difficult to get reliable analytical values for low carbonate samples in the presence of $15 \mathrm{M}_{\text {hydroxide }}^{\mathrm{a}}$.

\footnotetext{
${ }^{a}$ Both laboratories analyzed for carbonate by two different methods (TIC/TOC by SRNL-AD and titration by F/H Lab).
} 
This along with heating of Tanks 30 and 37 samples by F/H Laboratory to match the tank temperatures prior to sampling for analyses may lead to different analytical results when compared to the SRNL-AD results for these components of Tanks 30 and 37. SRNL-AD did not heat the samples. However, it is worth noting that the SRNL-AD reagent or matrix blanks and cell blanks for silicon were high. So, there may be some silicon contamination issues which need to address by SRNL-AD.

The large measures of relative differences between the two laboratory results for these anions and cations were also observed in some of the 2008 cross-check measurements.

Based on discussions with the liquid waste customer, none of these results present a significant concern in the current measurement of process samples or the Tank Farm. The measurement of carbonate and anions such as sulfate, phosphate, and chlorides are performed to evaluate impacts in the ionic strength of the samples. If the carbonate and other anions are low, their impact on the ionic strength would be negligible. Also, while silicon is low for these samples, typical measurements at SRNL are performed on the $2 \mathrm{H}$ evaporator tanks, which have higher concentration of silicon, which minimizes the impact of the silicon in the blank.

Recommendation to enhance the goals of cross-check comparisons between the two laboratories includes the following:

- Both laboratories (SRNL-AD and F/H laboratories) should work on method improvements to enhance analyzes for both silicon and carbonate at low concentrations.

- Although it is non-routine for SRNL-AD group to heat tank samples to specific tank temperature prior to analysis for cations and anions, it will be useful for the sake of these types of comparative analyses between the two laboratories for SRNL-AD to heat the samples to the same temperature that $\mathrm{F} / \mathrm{H}$ laboratory treats the samples prior to analysis. This temperature treatment will eliminate the problems associated with changes in sample density, precipitation and uneven sample pipetting and deliveries

- If possible, both laboratories should employ the same analytical methods in all these analyses. 
Table 2 Cross Check Analysis: Tank 30 Analyses: SRNL and F/H Laboratory Average Result Values Compared-Surface and Variable depth Samples@

\begin{tabular}{|c|c|c|c|c|c|c|c|}
\hline \multicolumn{3}{|c|}{ SRNL: HTF-30-12-06 and HTF-30-12-07 } & \multicolumn{4}{|c|}{ F/H Lab.: HTF-30-12-01 and HTF-30-12-02 } & \multirow[b]{2}{*}{ Units } \\
\hline Analyte & $\begin{array}{c}\text { HTF 30-12-06 } \\
\text { surface } \\
\text { Average }\end{array}$ & $\begin{array}{c}\text { HTF 30-12-07 } \\
\text { Variable Depth } \\
\text { Average } \\
\end{array}$ & $\begin{array}{c}\text { HTF-30-12-01 } \\
\text { surface } \\
\text { Average }\end{array}$ & $\begin{array}{c}\text { HTF-30-12-02 } \\
\text { Variable Depth } \\
\text { Average }\end{array}$ & $\begin{array}{c}\text { \%RD } \\
\text { Surface }\end{array}$ & $\begin{array}{l}\text { \%RD } \\
\text { VDS }\end{array}$ & \\
\hline Specific gravity & 1.45 & 1.46 & 1.4154 & $\mathbf{1 . 4 5 3 7}$ & 2.42 & 0.43 & \\
\hline $\mathbf{p} \mathbf{H}^{+}$ & 14.8 & 15.0 & 14.81 & 14.86 & 0.0 & 0.90 & \\
\hline Nitrite, $\mathrm{NO}_{2}$ & $1.93 E+00$ & $1.77 \mathbf{E}+00$ & 2.0061 & - & 3.81 & - & moles/L \\
\hline Nitrate, $\mathrm{NO}_{3}$ & $1.68 \mathrm{E}+00$ & $1.28 E+00$ & $\mathbf{1 . 8 3 2 0}$ & - & 8.66 & - & moles/L \\
\hline Aluminum, Al & 6.44E-01 & $7.80 \mathrm{E}-01$ & 0.4243 & 0.5195 & 41.1 & 40.1 & moles/L \\
\hline Sulfate, $\mathrm{SO}_{4}$ & $6.65 E-03$ & 2.888E-03 & 0.0134 & 0.0095 & 67.4 & 107 & moles/L \\
\hline Carbonate, $\mathrm{CO}_{3}$ & $7.08 \mathrm{E}-02$ & 4.11E-02 & 0.1260 & 0.1238 & 56.1 & 100 & moles/L \\
\hline Sodium, Na & $1.34 \mathrm{E}+01$ & $1.47 \mathrm{E}+01$ & 9.0638 & 10.7713 & 38.9 & 31.1 & moles/L \\
\hline Phosphate $\mathrm{PO}_{4}$ & $7.68 \mathrm{E}-03$ & $9.69 \mathrm{E}-03$ & 0.0093 & 0.0107 & 19.1 & 9.9 & moles/L \\
\hline Oxalate, $\mathrm{C}_{2} \mathrm{O}_{4}$ & $\leq 2.96 \mathrm{E}-03$ & $<3.00 \mathrm{E}-03$ & $<6.84 \mathrm{E}-03$ & $<6.84 \mathrm{E}-03$ & & & moles/L \\
\hline Silicon Si & $1.52 \mathrm{E}-03$ & $1.45 \mathrm{E}-03$ & 7.0E-04 & 7.0E-04 & 73.8 & 69.8 & moles/L \\
\hline Chloride, Cl & 1.62E-02 & $1.78 \mathrm{E}-02$ & - & - & - & - & moles/L \\
\hline Free-OH & 6.42 & 9.63 & 6.4247 & 7.2239 & $\mathbf{0 . 0 7}$ & 28.6 & moles/L \\
\hline Cs-137 & $3.57 \mathrm{E}+09$ & $4.56 \mathrm{E}+09$ & $3.14 \mathrm{E}+09$ & - & 12.8 & & $\mathrm{dpm} / \mathrm{mL}$ \\
\hline
\end{tabular}

+ Based on average $[\mathrm{OH}]$

*Free-OH @ $0.1 \mathrm{~N}$ titrant by SRNL

**Free-OH @ 0.01 N titrant by F/H Lab.

@The following color codes are used for the table contents: Green for highlighted entries for analytes with percent relative deviation greater than 20\%, and bold for averages. All subsequent tables have similar color code meanings. 
Table 3 Cross Check Analysis: Tank 37 Analyses: SRNL and F/H Laboratory Average Result Values Compared-Surface and Variable depth Samples

\begin{tabular}{|c|c|c|c|c|c|c|c|}
\hline \multicolumn{3}{|c|}{ SRNL: HTF-37-12-08 and HTF-37-12-09 } & \multicolumn{4}{|c|}{ F/H Lab.: HTF-37-12-04 and HTF-37-12-05 } & \multirow[b]{2}{*}{ Units } \\
\hline Analyte & $\begin{array}{c}\text { HTF-37-12-08 } \\
\text { surface } \\
\text { Average }\end{array}$ & $\begin{array}{c}\text { HTF-37-12-09 } \\
\text { Variable Depth } \\
\text { Average }\end{array}$ & $\begin{array}{c}\text { HTF-37-12-04 } \\
\text { surface } \\
\text { Average }\end{array}$ & $\begin{array}{c}\text { HTF-37-12-05 } \\
\text { Variable Depth } \\
\text { Average }\end{array}$ & $\begin{array}{c}\text { \%RD } \\
\text { Surface }\end{array}$ & $\begin{array}{l}\text { \%RD } \\
\text { VDS }\end{array}$ & \\
\hline Specific gravity & 1.49 & 1.51 & 1.4886 & 1.4811 & 0.09 & 1.93 & \\
\hline $\mathbf{p} \mathbf{H}^{+}$ & 15.1 & 15.1 & 15.04 & 15.02 & 0.20 & 0.40 & \\
\hline Nitrite, $\mathrm{NO}_{2}$ & $1.42 \mathrm{E}+00$ & $1.47 \mathrm{E}+00$ & $1.7724 \mathrm{E}+00$ & - & 21.9 & - & moles/L \\
\hline Nitrate, $\mathrm{NO}_{3}$ & $1.13 \mathrm{E}+00$ & $1.24 \mathrm{E}+00$ & $1.2455 \mathrm{E}+00$ & - & 9.46 & - & moles/L \\
\hline Aluminum, Al & 6.76E-01 & 6.61E-01 & $6.156 \mathrm{E}-01$ & 6.631E-01 & 9.35 & 0.32 & moles/L \\
\hline Sulfate, $\mathrm{SO}_{4}$ & $<2.79 \mathrm{E}-03$ & $<2.68 \mathrm{E}-03$ & $<6.3 \mathrm{E}-03$ & $6.2 \mathrm{E}-03$ & & & moles/L \\
\hline Carbonate, $\mathrm{CO}_{3}$ & 4.08E-02 & 3.71E-02 & $1.608 \mathrm{E}-01$ & $1.443 \mathrm{E}-01$ & 119 & 118 & moles/L \\
\hline Sodium, Na & $1.61 \mathrm{E}+01$ & $1.61 \mathrm{E}+01$ & 13.2644 & 12.4343 & 19.4 & 25.9 & moles/L \\
\hline Phosphate $\mathrm{PO}_{4}$ & 1.37E-02 & 1.27E-02 & $1.53 \mathrm{E}-02$ & $1.41 \mathrm{E}-02$ & 11.3 & 10.4 & moles/L \\
\hline Oxalate, $\mathrm{C}_{2} \mathrm{O}_{4}$ & $<3.040 \mathrm{E}-03$ & $<2.92 \mathrm{E}-03$ & $<6.86 \mathrm{E}-03$ & $<6.74 \mathrm{E}-03$ & & & moles/L \\
\hline Silicon Si & $1.33 E-03$ & 1.33E-03 & $7.00 \mathrm{E}-04$ & 8.00E-04 & 62.1 & 49.8 & moles/L \\
\hline Chloride, Cl & $2.26 \mathrm{E}-02$ & $1.70 \mathrm{E}-02$ & - & - & - & - & moles/L \\
\hline Free-OH & $11.8^{*}$ & 11.9* & $10.9437 * *$ & $10.4673 * *$ & 7.28 & 12.81 & moles/L \\
\hline Cs-137 & $5.00 \mathrm{E}+09$ & $5.32 \mathrm{E}+09$ & $5.45 \mathrm{E}+09$ & - & 8.61 & - & $\mathrm{dpm} / \mathrm{mL}$ \\
\hline
\end{tabular}

${ }^{+}$Based on average $[\mathrm{OH}]$

*Free-OH @ $0.1 \mathrm{~N}$ titrant by SRNL

**Free-OH @ 0.01 N titrant by F/H Lab. 
Table 4 Cross Check Analysis: Tank 30 Analyses: SRNL and F/H (SPLIT Sample) Laboratory Results Compared-Surface and Variable depth Samples.

\begin{tabular}{|c|c|c|c|c|c|c|c|}
\hline \multicolumn{3}{|c|}{ SRNL: HTF-30-12-06 and HTF-30-12-07 } & \multicolumn{4}{|c|}{ F/H Lab.: HTF-30 SPLIT SAMPLE } & \multirow[b]{2}{*}{ Units } \\
\hline Analyte & $\begin{array}{c}\text { HTF-30-12-06 } \\
\text { surface } \\
\text { Average }\end{array}$ & $\begin{array}{c}\text { HTF-30-12-07 } \\
\text { Variable Depth } \\
\text { Average }\end{array}$ & $\begin{array}{c}\text { HTF-30-12-6-F/H } \\
\text { surface } \\
\text { Average }\end{array}$ & $\begin{array}{c}\text { HTF-30-12-7-F/H } \\
\text { Variable Depth } \\
\text { Average }\end{array}$ & $\begin{array}{c}\% \text { RD } \\
\text { Surface }\end{array}$ & $\begin{array}{l}\text { \%RD } \\
\text { VDS }\end{array}$ & \\
\hline Specific gravity & 1.45 & 1.46 & 1.4591 & 1.4561 & 0.63 & 0.27 & \\
\hline $\mathbf{p H}$ & 14.8 & 15.0 & 14.87 & 14.96 & 0.40 & 0.13 & \\
\hline Nitrite, $\mathrm{NO}_{2}$ & $1.93 \mathrm{E}+00$ & $1.77 \mathrm{E}+00$ & 2.1932 & 2.0576 & 12.7 & 15.2 & moles/L \\
\hline Nitrate, $\mathrm{NO}_{3}$ & $1.68 \mathrm{E}+00$ & $1.28 \mathrm{E}+00$ & 1.884 & 1.429 & 11.2 & 10.9 & moles/L \\
\hline Aluminum, Al & 0.644 & 0.78 & 6.037E-01 & $7.096 \mathrm{E}-01$ & 6.46 & 9.45 & moles/L \\
\hline Sulfate, $\mathrm{SO}_{4}$ & 6.65E-03 & 2.88E-03 & $1.16 \mathrm{E}-02$ & $6.35 E-03$ & 54.3 & 75.3 & moles/L \\
\hline Carbonate, $\mathrm{CO}_{3}$ & 7.08E-02 & 4.11E-02 & 6.445E-02 & 6.55E-02 & 9.35 & 45.8 & moles/L \\
\hline Sodium, Na & 13.44 & 14.74 & 12.316 & 12.714 & 8.7 & 14.8 & moles/L \\
\hline Phosphate $\mathrm{PO}_{4}$ & $7.68 \mathrm{E}-03$ & $9.69 \mathrm{E}-03$ & $1.06 \mathrm{E}-02$ & $1.40 \mathrm{E}-02$ & 32.0 & 36.4 & moles/L \\
\hline Oxalate, $\mathrm{C}_{2} \mathrm{O}_{4}$ & $\leq 2.96 \mathrm{E}-03$ & $<3.00 \mathrm{E}-03$ & $<2.81 \mathrm{E}-03$ & $<2.81 \mathrm{E}-03$ & & & moles/L \\
\hline Silicon Si & $1.52 \mathrm{E}-03$ & $1.45 \mathrm{E}-03$ & $7.885 E-04$ & 5.085E-04 & 63.4 & 96.2 & moles/L \\
\hline Chloride, Cl & $1.62 \mathrm{E}-02$ & $1.78 \mathrm{E}-02$ & 2.055E-02 & $2.405 E-02$ & 23.9 & 29.9 & moles/L \\
\hline Free-OH & $6.42 *$ & $9.63 *$ & $7.477 * *$ & $9.204 * *$ & 15.2 & 4.5 & moles/L \\
\hline Cs-137 & $3.57 \mathrm{E}+09$ & $4.56 \mathrm{E}+09$ & $3.53 E+09$ & - & 1.13 & - & $\mathrm{dpm} / \mathrm{mL}$ \\
\hline
\end{tabular}

*Free-OH @ $0.1 \mathrm{~N}$ titrant by SRNL

**Free-OH@ $0.01 \mathrm{~N}$ titrant by F/H Lab. 
Table 5 Cross Check Analysis: Tank 37 Analyses: SRNL and F/H (SPLIT Sample) Laboratory Results Compared-Surface and Variable depth Samples.

\begin{tabular}{|c|c|c|c|c|c|c|c|}
\hline \multicolumn{3}{|c|}{ SRNL: HTF-37-12-08 and HTF-37-12-09 } & \multicolumn{4}{|c|}{ F/H Lab.: HTF-37-SPLIT SAMPLE } & \multirow[b]{2}{*}{ Units } \\
\hline Analyte & $\begin{array}{c}\text { HTF-37-12-08 } \\
\text { surface } \\
\text { Average }\end{array}$ & $\begin{array}{c}\text { HTF-37-12-09 } \\
\text { Variable } \\
\text { Depth } \\
\text { Average }\end{array}$ & $\begin{array}{c}\text { HTF-37-12-8- } \\
\text { F/H } \\
\text { surface } \\
\text { Average }\end{array}$ & $\begin{array}{c}\text { HTF-37-12-9-F/H } \\
\text { Variable Depth } \\
\text { Average }\end{array}$ & $\begin{array}{c}\text { \%RD } \\
\text { Surface }\end{array}$ & $\begin{array}{l}\text { \%RD } \\
\text { VDS }\end{array}$ & \\
\hline Specific gravity & 1.49 & 1.51 & 1.4933 & 1.4883 & 0.22 & 1.45 & \\
\hline pH & 15.1 & 15.1 & 15.06 & 15.07 & 0.07 & 0.07 & \\
\hline Nitrite, $\mathrm{NO}_{2}$ & $1.42 \mathrm{E}+00$ & $1.47 \mathrm{E}+00$ & 1.6286 & 1.537 & 13.5 & 4.5 & moles/L \\
\hline Nitrate, $\mathrm{NO}_{3}$ & $1.13 E+00$ & $1.24 \mathrm{E}+00$ & 1.2185 & 1.1715 & 7.27 & 6.00 & moles/L \\
\hline Aluminum, Al & $6.76 \mathrm{E}-01$ & 6.61E-01 & 5.52E-01 & 6.18E-01 & 20.2 & 6.72 & moles/L \\
\hline Sulfate, $\mathrm{SO}_{4}$ & $<2.79 \mathrm{E}-03$ & $<2.68 \mathrm{E}-03$ & 0.003 & 0.0029 & & & moles/L \\
\hline Carbonate, $\mathrm{CO}_{3}$ & 4.08E-02 & 3.71E-02 & 0.0538 & 0.0514 & 27.6 & 32.3 & moles/L \\
\hline Sodium, Na & 16.1 & 16.1 & 14.085 & 14.081 & 13.5 & 13.6 & moles/L \\
\hline Phosphate $\mathrm{PO}_{4}$ & 1.37E-02 & $1.27 \mathrm{E}-02$ & 0.0193 & 0.0191 & 34.2 & 40.2 & moles/L \\
\hline Oxalate, $\mathrm{C}_{2} \mathrm{O}_{4}$ & $<3.040 \mathrm{E}-03$ & $<2.92 \mathrm{E}-03$ & $<2.78 \mathrm{E}-03$ & $<2.76 \mathrm{E}-03$ & & & moles/L \\
\hline Silicon Si & 1.33E-03 & 1.33E-03 & 7.0E-04 & $7.5 E-04$ & 62.1 & 55.8 & moles/L \\
\hline Chloride, $\mathrm{Cl}$ & $2.26 \mathrm{E}-02$ & 1.70E-02 & 2.99E-02 & 3.08E-02 & 27.6 & 57.6 & moles/L \\
\hline Free-OH * & $11.77 *$ & $11.90 *$ & $11.500 * *$ & $11.68 * *$ & 2.32 & 1.87 & moles/L \\
\hline Cs-137 & $5.00 \mathrm{E}+09$ & $5.32 \mathrm{E}+09$ & $5.20 \mathrm{E}+09$ & - & 3.92 & - & $\mathrm{dpm} / \mathrm{mL}$ \\
\hline
\end{tabular}

**Free-OH @ $0.01 \mathrm{~N}$ titrant by F/H Lab. 
SRNL-STI-2012-00550 Rev. 0

Table 6 Summary of Analytical comparisons between the two laboratories for analytical components of Tank 30 and 37.

\begin{tabular}{|c|c|c|c|c|c|c|c|c|c|}
\hline Analyte & $\begin{array}{l}\text { Tank } 30 \\
\text { surface }\end{array}$ & $\begin{array}{c}\text { Tank } 30 \\
\text { VDS }\end{array}$ & $\begin{array}{l}\text { Tank } 37 \\
\text { surface }\end{array}$ & $\begin{array}{c}\text { Tank } 37 \\
\text { VDS }\end{array}$ & $\begin{array}{c}\text { Tank } 30 \\
\text { surface } \\
\text { Split }\end{array}$ & $\begin{array}{c}\text { Tank 30 } \\
\text { VDS } \\
\text { Split } \\
\end{array}$ & $\begin{array}{c}\text { Tank } 37 \\
\text { surface } \\
\text { Split } \\
\end{array}$ & $\begin{array}{c}\text { Tank } 37 \\
\text { VDS Split }\end{array}$ & $\begin{array}{c}\text { Comparative* } \\
\text { Analytical } \\
\text { Performance, \% }\end{array}$ \\
\hline Sp. gravity & & & & & & & & & $\begin{array}{c}0.0 \\
\end{array}$ \\
\hline $\mathrm{pH}$ & & & & & & & & & 0.0 \\
\hline Nitrite & & & $\mathbf{X}$ & & & & & & 12.5 \\
\hline Nitrate & & & & & & & & & 0.0 \\
\hline Aluminum & $\mathbf{X}$ & $\mathbf{X}$ & & & & & & & 25 \\
\hline Sulfate & $\mathbf{X}$ & $\mathbf{X}$ & & & $\mathbf{X}$ & $\mathbf{X}$ & & & 50 \\
\hline Carbonate & $\mathbf{X}$ & $\mathbf{X}$ & $\mathbf{X}$ & $\mathbf{X}$ & & $\mathbf{X}$ & $\mathbf{X}$ & $\mathbf{X}$ & 87.5 \\
\hline Sodium & $\mathbf{X}$ & $\mathbf{X}$ & & $\mathbf{X}$ & & & & & 37.5 \\
\hline Phosphate & & & & & $\mathbf{X}$ & $\mathbf{X}$ & $\mathbf{X}$ & $\mathbf{X}$ & $\mathbf{5 0}$ \\
\hline Oxalate & & & & & & & & & $\mathbf{0 . 0}$ \\
\hline Silicon & $\mathbf{X}$ & $\mathbf{X}$ & $\mathbf{X}$ & $\mathbf{X}$ & $\mathbf{X}$ & $\mathbf{X}$ & $\mathbf{X}$ & $\mathbf{X}$ & 100 \\
\hline Chloride & - & - & - & - & $\mathbf{X}$ & $\mathbf{X}$ & $\mathbf{X}$ & $\mathbf{X}$ & 100 \\
\hline Free-OH & & $\mathbf{X}$ & & & & & & & 12.5 \\
\hline Cs-137 & & & & & & & & & 0.0 \\
\hline
\end{tabular}

*As a percent of the number of times analyses was performed by both laboratories for that analyte. A measure of $100 \%$ indicates laboratory analytical results were quite different for the same analyte, while a $0 \%$ implies both analytical results were in full agreement in all the analyses results.

$\mathrm{X}$ indicates analytical result for that component between the two laboratories (F/H and SRNL) NOT comparable, i.e., \%RD greater than 20\%. 


\subsection{References}

1) Technical Task Request (TTR) number X-TTR-2012-00016.

2) L. N. Oji, “Task Technical and Quality Assurance Plan for the Characterization of Tank Supernate Samples: Cross-Check and Evaporator Feed Quality Analysis for tanks 30 and 37, SRNL-RP-2012-00151, Rev. 0.

3) L. N. Oji, "F/H Laboratory and SRNL Cross-check Comparison of High Level Waste Tank 39H Supernatant Sample -2008”

SRNL-TR-2009-00141, Rev. 0, October 2008. 


\section{Appendix A}

Table 7.Cross Check Analysis for Tanks 30 Samples-Duplicate SRNL analysis: Tank 30 Surface and Variable Depth

\begin{tabular}{|c|c|c|c|c|c|c|c|c|c|}
\hline \multicolumn{5}{|c|}{ HTF-30-12-06----SRNL: Surface } & \multicolumn{5}{|c|}{ HTF-30-12-07-----SRNL: Variable Depth } \\
\hline Analyte & Run-1 & Run- 2 & Average & St. dev & Run-1 & Run- 2 & Average & St. dev & Units \\
\hline Sp. gravity & 1.43 & 1.46 & $1.45 * *$ & 0.02 & 1.450 & 1.45 & $1.46 * *$ & 0.03 & \\
\hline $\mathrm{pH}$ & 14.8 & 14.80 & $14.8^{*}$ & - & 15.0 & 15.0 & 15.0 & - & \\
\hline Nitrite, $\mathrm{NO}_{2}$ & $1.94 \mathrm{E}+00$ & $1.92 \mathrm{E}+00$ & $1.93 \mathrm{E}+00$ & $1.37 E-02$ & $1.77 \mathrm{E}+00$ & $1.76 \mathrm{E}+00$ & $1.77 \mathrm{E}+00$ & $8.26 E-03$ & moles/L \\
\hline Nitrate, $\mathrm{NO}_{3}$ & $1.70 \mathrm{E}+00$ & $1.67 \mathrm{E}+00$ & $1.68 \mathrm{E}+00$ & $2.01 E-02$ & $1.28 \mathrm{E}+00$ & $1.29 \mathrm{E}+00$ & $1.28 \mathrm{E}+00$ & $6.15 E-03$ & moles/L \\
\hline Aluminum, Al & $6.41 \mathrm{E}-01$ & $6.48 \mathrm{E}-01$ & $6.44 \mathrm{E}-01$ & $5.24 E-03$ & $7.85 \mathrm{E}-01$ & 7.74E-01 & $7.80 \mathrm{E}-01$ & $7.86 E-03$ & moles/L \\
\hline Sulfate, $\mathrm{SO}_{4}$ & $6.87 \mathrm{E}-03$ & 6.42E-03 & $6.65 E-03$ & $3.18 E-04$ & $2.96 \mathrm{E}-03$ & $2.80 \mathrm{E}-03$ & $2.88 E-03$ & $1.13 E-04$ & moles/L \\
\hline Carbonate, $\mathrm{CO}_{3}$ & $6.82 \mathrm{E}-02$ & 7.33E-02 & $7.08 \mathrm{E}-02$ & $3.63 E-03$ & $4.02 \mathrm{E}-02$ & 4.20E-02 & 4.11E-02 & $1.22 E-03$ & moles/L \\
\hline Sodium, Na & $1.32 \mathrm{E}+01$ & $1.37 \mathrm{E}+01$ & $1.34 \mathrm{E}+01$ & 3.61E-01 & $1.50 \mathrm{E}+01$ & $1.44 \mathrm{E}+01$ & $1.47 \mathrm{E}+01$ & $4.20 \mathrm{E}-01$ & moles/L \\
\hline Phosphate $\mathrm{PO}_{4}$ & $7.78 \mathrm{E}-03$ & 7.57E-03 & $7.68 \mathrm{E}-03$ & $1.46 E-04$ & $9.78 \mathrm{E}-03$ & $9.61 \mathrm{E}-03$ & 9.69E-03 & $1.18 E-04$ & moles/L \\
\hline Oxalate, $\mathrm{C}_{2} \mathrm{O}_{4}$ & $<0.0 \mathrm{E}+\mathbf{0}$ & $\leq 2.92 \mathrm{E}-03$ & $\leq 2.96 \mathrm{E}-03$ & & $<2.93 \mathrm{E}-03$ & $<3.05 \mathrm{E}-03$ & $<2.99 \mathrm{E}-03$ & & moles/L \\
\hline Silicon, Si & 1.53E-03 & $1.52 \mathrm{E}-03$ & $1.52 \mathrm{E}-03$ & $7.58 E-06$ & $1.48 \mathrm{E}-03$ & $1.42 \mathrm{E}-03$ & $1.45 \mathrm{E}-03$ & $4.29 E-05$ & moles/L \\
\hline Chloride, $\mathrm{Cl}$ & $1.64 \mathrm{E}-02$ & 1.59E-02 & $1.62 \mathrm{E}-02$ & $3.07 E-04$ & $1.82 \mathrm{E}-02$ & $1.74 \mathrm{E}-02$ & $1.78 \mathrm{E}-02$ & $5.47 E-04$ & moles/L \\
\hline Free-OH & 6.73 & 6.10 & 6.42 & 0.45 & 9.67 & 9.59 & 9.63 & 0.06 & moles/L \\
\hline Cs-137 & $3.57 \mathrm{E}+09$ & $3.56 \mathrm{E}+09$ & $3.57 \mathrm{E}+09$ & $8.85 E+06$ & $4.53 \mathrm{E}+09$ & $4.59 \mathrm{E}+09$ & $4.56 \mathrm{E}+09$ & $3.94 E+07$ & $\mathrm{dpm} / \mathrm{mL}$ \\
\hline
\end{tabular}

** Calculated from three values (only two shown). 
Table 8Cross Check Analysis for Tanks 37 Samples-Duplicate SRNL analysis Tank 37 Surface and Variable Depth

\begin{tabular}{|c|c|c|c|c|c|c|c|c|c|}
\hline \multicolumn{5}{|c|}{ HTF-37-12-08----SRNL: Surface } & \multicolumn{5}{|c|}{ HTF-37-12-09-----SRNL: Variable Depth } \\
\hline Analyte & Run-1 & Run- 2 & Average & St. dev & Run-1 & Run- 2 & Average & St. dev & Units \\
\hline Sp. gravity & 1.47 & 1.51 & $1.49 * *$ & 0.021 & 1.50 & 1.50 & $1.51 * *$ & 0.01 & - \\
\hline $\mathrm{pH}$ & 15.1 & 15.1 & 15.1* & 0 & 15.1 & 15.1 & 15.1 & & \\
\hline Nitrite, $\mathrm{NO}_{2}$ & $1.36 \mathrm{E}+00$ & $1.48 \mathrm{E}+00$ & $1.42 \mathrm{E}+00$ & $8.67 E-02$ & $1.56 \mathrm{E}+00$ & $1.38 \mathrm{E}+00$ & $1.47 \mathrm{E}+00$ & $1.21 E-01$ & moles/L \\
\hline Nitrate, $\mathrm{NO}_{3}$ & $1.08 \mathrm{E}+00$ & $1.19 \mathrm{E}+00$ & $1.13 E+00$ & $7.76 E-02$ & $1.30 \mathrm{E}+00$ & $1.19 \mathrm{E}+00$ & $1.24 \mathrm{E}+00$ & $7.32 E-02$ & moles/L \\
\hline Aluminum, $\mathrm{Al}$ & 6.67E-01 & 6.85E-01 & 6.76E-01 & $1.31 E-02$ & 6.85E-01 & 6.37E-01 & 6.61E-01 & $3.40 E-02$ & moles/L \\
\hline Sulfate, $\mathrm{SO}_{4}$ & $<2.71 \mathrm{E}-03$ & $<2.86 \mathrm{E}-03$ & $<2.79 \mathrm{E}-03$ & & $<2.70 \mathrm{E}-03$ & $<2.65 \mathrm{E}-03$ & $<2.68 \mathrm{E}-03$ & & moles/L \\
\hline Carbonate, $\mathrm{CO}_{3}$ & $3.80 \mathrm{E}-02$ & 4.36E-02 & 4.08E-02 & $3.96 E-03$ & 3.66E-02 & $3.76 \mathrm{E}-02$ & $3.71 \mathrm{E}-02$ & $7.27 E-04$ & moles/L \\
\hline Sodium, $\mathrm{Na}$ & 16.0 & 16.3 & $1.61 \mathrm{E}+01$ & $2.14 E-01$ & $1.56 \mathrm{E}+01$ & $1.67 \mathrm{E}+01$ & $1.61 \mathrm{E}+01$ & 8.27E-01 & moles/L \\
\hline Phosphate $\mathrm{PO}_{4}$ & $1.32 \mathrm{E}-02$ & $1.42 \mathrm{E}-02$ & $1.37 \mathrm{E}-02$ & $7.30 E-04$ & $1.28 \mathrm{E}-02$ & $1.26 \mathrm{E}-02$ & $1.27 \mathrm{E}-02$ & $1.61 E-04$ & moles/L \\
\hline Oxalate, $\mathrm{C}_{2} \mathrm{O}_{4}$ & $<2.96 \mathrm{E}-03$ & $<3.12 \mathrm{E}-03$ & $<3.04 \mathrm{E}-03$ & & $<2.94 \mathrm{E}-03$ & $<2.89 \mathrm{E}-03$ & $<2.92 \mathrm{E}-03$ & & moles/L \\
\hline Silicon, Si & 1.53E-03 & 1.13E-03 & $1.33 E-03$ & 2.83E-04 & 1.33E-03 & 1.32E-03 & 1.33E-03 & $7.58 E-06$ & moles/L \\
\hline Chloride, $\mathrm{Cl}$ & $2.20 \mathrm{E}-02$ & 2.33E-02 & $2.26 \mathrm{E}-02$ & $8.80 E-04$ & $1.83 \mathrm{E}-02$ & $1.58 \mathrm{E}-02$ & 1.70E-02 & $1.75 E-03$ & moles/L \\
\hline Free-OH & 11.74 & 11.81 & 11.77 & 0.05 & 12.23 & 11.57 & 11.90 & 0.47 & moles/L \\
\hline Cs-137 & $5.06 \mathrm{E}+09$ & $4.93 \mathrm{E}+09$ & $5.00 \mathrm{E}+09$ & $9.63 E+07$ & $5.36 \mathrm{E}+09$ & $5.28 \mathrm{E}+09$ & $5.32 \mathrm{E}+09$ & $5.91 E+07$ & $\mathrm{dpm} / \mathrm{mL}$ \\
\hline
\end{tabular}

*Based on average [OH]

** Calculated from three values (only two shown). 
Table 9. Check Analysis for Tanks 30 Samples- F/H analysis Tank 30 Surface and Variable Depth.

\begin{tabular}{|c|c|c|c|c|c|c|c|c|c|}
\hline \multicolumn{4}{|c|}{ HTF-30-12-01---F/H: Surface } & \multicolumn{3}{c|}{ HTF-30-12-02---F/H: Variable Depth } \\
\hline Analyte & Run-1 & Run- 2 & Average & St. dev & Run-1 & Run- 2 & Average & St. dev & Units \\
\hline & & & & & & & & & \\
\hline Specific gravity & 1.4154 & NA & & & 1.4537 & NA & & & - \\
\hline Nitrite, $\mathrm{NO}_{2}$ & 2.0061 & NA & & & NA & NA & & & moles/L \\
\hline Nitrate, $\mathrm{NO}_{3}$ & 1.8320 & NA & & & NA & NA & & & moles/L \\
\hline Aluminum, $\mathrm{Al}$ & 0.4243 & NA & & & 0.5195 & NA & & & moles/L \\
\hline Sulfate, $\mathrm{SO}_{4}$ & 0.0134 & NA & & & 0.0095 & NA & & & moles/L \\
\hline Carbonate, $\mathrm{CO}_{3}$ & 0.1260 & NA & & & 0.1238 & NA & & & moles/L \\
\hline Sodium, $\mathrm{Na}$ & 9.0638 & NA & & & 10.7713 & NA & & & moles/L \\
\hline Phosphate $\mathrm{PO}_{4}$ & 0.0093 & NA & & & 0.0107 & NA & & & moles/L \\
\hline Oxalate, $\mathrm{C}_{2} \mathrm{O}_{4}$ & $<602$ & NA & & & $<602$ & NA & & & $\mathrm{mg} / \mathrm{L}$ \\
\hline Silicon, $\mathrm{Si}$ & 0.0007 & NA & & & 0.0007 & NA & & & moles/L \\
\hline Free-OH & 6.4247 & NA & & & 7.2239 & NA & & & moles/L \\
\hline Cs-137 & $3.14 \mathrm{E} 09$ & NA & & & NA & NA & & & dpm/mL \\
\hline
\end{tabular}

Table 10. Cross Check Analysis for Tanks 37 Samples- F/H analysis Tank 37 Surface and Variable Depth

\begin{tabular}{|c|c|c|c|c|c|c|c|c|c|}
\hline \multicolumn{4}{|c|}{ HTF-37-12-04---F/H: Surface } & \multicolumn{3}{c|}{ HTF-37-12-05----F/H: Variable Depth } \\
\hline Analyte & Run-1 & Run- 2 & Average & St. dev & Run-1 & Run- 2 & Average & St. dev & Units \\
\hline & & & & & & & & & \\
\hline Specific gravity & 1.4886 & NA & & & 1.4811 & NA & & & - \\
\hline Nitrite, $\mathrm{NO}_{2}$ & 1.7724 & NA & & & NA & NA & & & moles/L \\
\hline Nitrate, $\mathrm{NO}_{3}$ & 1.2455 & NA & & & NA & NA & & & moles/L \\
\hline Aluminum, $\mathrm{Al}$ & 0.6156 & NA & & & 0.6631 & NA & & & moles/L \\
\hline Sulfate, $\mathrm{SO}_{4}$ & $<0.0063$ & NA & & & 0.0062 & NA & & & moles/L \\
\hline Carbonate, $\mathrm{CO}_{3}$ & 0.1608 & NA & & & 0.1443 & NA & & & moles/L \\
\hline Sodium, $\mathrm{Na}$ & 13.2644 & NA & & & 12.4343 & NA & & & moles/L \\
\hline Phosphate $\mathrm{PO}_{4}$ & 0.0153 & NA & & & 0.0141 & NA & & & moles/L \\
\hline Oxalate, $\mathrm{C}_{2} \mathrm{O}_{4}$ & $<604$ & NA & & & $<593$ & NA & & & $\mathrm{mg} / \mathrm{L}$ \\
\hline Silicon, $\mathrm{Si}$ & 0.0007 & NA & & & 0.0008 & NA & & & $\mathrm{moles} / \mathrm{L}$ \\
\hline Free-OH & 10.9437 & NA & & & 10.4673 & NA & & & moles/L \\
\hline Cs-137 & $5.45 E+09$ & NA & & & NA & NA & & & dpm/mL \\
\hline
\end{tabular}




\section{Appendix B}

Table 11. Cross Check Analysis for Tanks 30 Samples-Duplicate analysis-F/H-SPLIT SAMPLE

\begin{tabular}{|c|c|c|c|c|c|c|c|c|c|}
\hline \multicolumn{5}{|c|}{ HTF-30-12-06----F/H } & \multicolumn{5}{|c|}{ HTF-30-12-07-----F/H } \\
\hline Analyte & Run-1 & Run- 2 & Average & St. dev & Run-1 & Run- 2 & Average & St. dev & Units \\
\hline Specific gravity & 1.4591 & NA & $1.46 \mathrm{E}+00$ & & 1.4561 & NA & $1.46 \mathrm{E}+00$ & & - \\
\hline $\mathrm{pH}$ & NA & NA & & & NA & NA & & & \\
\hline Nitrite, $\mathrm{NO}_{2}$ & 2.1779 & 2.2085 & $2.19 \mathrm{E}+00$ & $2.16 E-02$ & 2.1122 & 2.003 & $2.06 \mathrm{E}+00$ & $7.72 E-02$ & moles/L \\
\hline Nitrate, $\mathrm{NO}_{3}$ & 1.8623 & 1.9057 & $1.88 \mathrm{E}+00$ & $3.07 E-02$ & 1.4562 & 1.4011 & $1.43 E+00$ & $3.90 E-02$ & moles/L \\
\hline Aluminum, $\mathrm{Al}$ & 0.5967 & 0.6106 & 6.04E-01 & $9.83 E-03$ & 0.6901 & 0.7291 & $7.10 \mathrm{E}-01$ & $2.76 E-02$ & moles/L \\
\hline Sulfate, $\mathrm{SO}_{4}$ & 0.0116 & 0.0116 & $1.16 \mathrm{E}-02$ & $0.00 E+00$ & 0.0064 & 0.0063 & $6.35 \mathrm{E}-03$ & $7.07 E-05$ & moles/L \\
\hline Carbonate, $\mathrm{CO}_{3}$ & 0.0580 & 0.0709 & 6.45E-02 & $9.12 E-03$ & 0.0592 & 0.0718 & $6.55 \mathrm{E}-02$ & $8.91 E-03$ & moles/L \\
\hline Sodium, Na & 12.3394 & 12.2923 & $1.23 \mathrm{E}+01$ & $3.33 E-02$ & 13.161 & 12.267 & $1.27 \mathrm{E}+01$ & $6.32 E-01$ & moles/L \\
\hline Phosphate $\mathrm{PO}_{4}$ & 0.0105 & 0.0106 & $1.06 \mathrm{E}-02$ & 7.07E-05 & 0.0144 & 0.0136 & $1.40 \mathrm{E}-02$ & $5.66 E-04$ & moles/L \\
\hline Oxalate, $\mathrm{C}_{2} \mathrm{O}_{4}$ & $<248$ & $<247$ & & & $<247$ & $<248$ & & & $\mathrm{ug} / \mathrm{mL}$ \\
\hline Silicon, Si & 0.000701 & 0.000876 & 7.89E-04 & $1.24 E-04$ & 0.000564 & 0.000453 & 5.09E-04 & $7.85 E-05$ & moles/L \\
\hline Chloride, $\mathrm{Cl}$ & 0.0204 & 0.0207 & $2.06 \mathrm{E}-02$ & $2.12 E-04$ & 0.0246 & 0.0235 & $2.41 \mathrm{E}-02$ & $7.78 E-04$ & moles/L \\
\hline Free-OH & 7.5041 & 7.4498 & $7.48 \mathrm{E}+00$ & $3.84 E-02$ & 9.3106 & 9.0982 & $9.20 \mathrm{E}+00$ & $1.50 E-01$ & moles/L \\
\hline Cs-137 & $3.55 E+09$ & $3.51 \mathrm{E}+09$ & $3.53 E+09$ & $2.83 E+07$ & NA & NA & & & $\mathrm{dpm} / \mathrm{mL}$ \\
\hline
\end{tabular}


Table 12. Cross Check Analysis for Tank 37 Samples-Duplicate analysis F/H-SPLIT SAMPLE

\begin{tabular}{|c|c|c|c|c|c|c|c|c|c|}
\hline \multicolumn{5}{|c|}{ HTF-37 SPLIT F/H >>>HTF-37-12-8 } & \multicolumn{5}{|c|}{ HTF-37 SPLIT F/H>>> HTF-37-12-9 } \\
\hline Analyte & Run-1 & Run- 2 & Average & St. dev & Run-1 & Run-2 & Average & St. dev & Units \\
\hline Specific gravity & 1.4933 & NA & $1.49 \mathrm{E}+00$ & & 1.4883 & NA & $1.49 \mathrm{E}+00$ & & - \\
\hline $\mathrm{pH}$ & NA & NA & & & NA & NA & & & \\
\hline Nitrite, $\mathrm{NO}_{2}$ & 1.6039 & 1.6533 & $1.63 E+00$ & $3.49 E-02$ & 1.5561 & 1.5179 & $1.54 \mathrm{E}+00$ & $2.70 E-02$ & moles/L \\
\hline Nitrate, $\mathrm{NO}_{3}$ & 1.2057 & 1.2312 & $1.22 \mathrm{E}+00$ & $1.80 E-02$ & 1.1917 & 1.1513 & $1.17 \mathrm{E}+00$ & $2.86 E-02$ & moles/L \\
\hline Aluminum, $\mathrm{Al}$ & 0.5657 & 0.5382 & 5.52E-01 & $1.94 E-02$ & 0.6124 & 0.6232 & 6.18E-01 & $7.64 E-03$ & moles/L \\
\hline Sulfate, $\mathrm{SO}_{4}$ & 0.0029 & 0.0031 & 3.00E-03 & $1.41 E-04$ & 0.0029 & 0.0029 & $2.90 \mathrm{E}-03$ & $0.00 E+00$ & moles/L \\
\hline Carbonate, $\mathrm{CO}_{3}$ & 0.0590 & 0.0486 & $5.38 \mathrm{E}-02$ & $7.35 E-03$ & 0.0528 & 0.0500 & 5.14E-02 & $1.98 E-03$ & moles/L \\
\hline Sodium, $\mathrm{Na}$ & 14.1006 & 14.0694 & $1.41 \mathrm{E}+01$ & $2.21 E-02$ & 14.1489 & 14.0121 & $1.41 \mathrm{E}+01$ & $9.67 E-02$ & moles/L \\
\hline Phosphate $\mathrm{PO}_{4}$ & 0.0192 & 0.0193 & 1.93E-02 & $7.07 E-05$ & 0.0194 & 0.0188 & $1.91 E-02$ & $4.24 E-04$ & moles/L \\
\hline Oxalate, $\mathrm{C}_{2} \mathrm{O}_{4}$ & $<245$ & $<246$ & & & $<242$ & $<245$ & & & $\mathrm{ug} / \mathrm{mL}$ \\
\hline Silicon, Si & 0.000647 & 0.000743 & 6.95E-04 & $6.79 E-05$ & 0.000792 & 0.00071 & $7.51 \mathrm{E}-04$ & $5.80 E-05$ & moles/L \\
\hline Chloride, $\mathrm{Cl}$ & 0.0296 & 0.0302 & 2.99E-02 & $4.24 E-04$ & 0.0311 & 0.0305 & 3.08E-02 & $4.24 E-04$ & moles/L \\
\hline Free-OH @ & 11.3911 & 11.5981 & $1.15 \mathrm{E}+01$ & $1.46 E-01$ & 11.7076 & 11.6583 & $1.17 \mathrm{E}+01$ & $3.49 E-02$ & moles/L \\
\hline Cs-137 & $5.23 E+09$ & $5.17 \mathrm{E}+09$ & $5.20 \mathrm{E}+09$ & $4.24 E+07$ & NA & NA & & & $\mathrm{dpm} / \mathrm{mL}$ \\
\hline
\end{tabular}




\section{Appendix C}

Analysis

HTF-30-12-6-IC-anion-1

HTF-30-12-6-IC-anion-2

HTF-30-12-6-Na-AA-1

HTF-30-12-6-Na-AA-2

HTF-30-12-6-Si-1

HTF-30-12-6-Si-2

HTF-30-12-6-Free-OH-1

HTF-30-12-6-Free-OH-2

HTF-30-12-7 IC-anion-1

HTF-30-12-7 IC-anion-2

HTF-30-12-7-Na-AA-1

HTF-30-12-7-Na-AA-2

HTF-30-12-7-Si-1

HTF-30-12-7-Si-2

HTF-30-12-7-Free-OH-1

HTF-30-12-7-Free-OH-2

HTF-37-12-8 IC-anion-1

HTF-37-12-8 IC-anion-2

HTF-37-12-8-Na-AA-1

HTF-37-12-8-Na-AA-2

HTF-37-12-8-Si-1

HTF-37-12-8-Si-2

HTF-37-12-8-Free-OH-1

HTF-37-12-8-Free-OH-2

HTF-37-12-9 IC-anion-1

HTF-37-12-9 IC-anion-2

HTF-37-12-9-Na-AA-1

HTF-37-12-9-Na-AA-2

HTF-37-12-9-Si-1

HTF-37-12-9-Si-2

HTF-37-12-9-Free-OH-1

HTF-37-12-9-Free-OH-2
LIMS Numbers for All SRNL Analyses ${ }^{+}$

Lims \#- HTF 30 and 37

300298622

300298623

300298647

300298648

300298638

300298639

300298630

300298631

300298624

300298625

300298649

300298650

300298640

300298641

300298632

300298633

300298626

300298627

300298651

300298652

300298642

300298643

300298634

300298635

300298628

300298629

300298653

300298654

300298644

300298645

300298636

300298637
Dilution factor

26.39

25.69

25.70

25.61

$+$

$+$

26.40

26.19

25.79

26.84

25.62

30.20

$+$

25.85

26.34

26.02

27.49

25.32

25.80

$+$

$+$

25.30

32.99

25.45

25.91

25.18

25.63

$+$

$+$

25.53

25.42
Comments

Including gamma scan Cs-137

Dissolution volume $=100 \mathrm{~mL}$

Dissolution volume $=100 \mathrm{~mL}$

Free-OH and carbonate

Free-OH and carbonate

Including gamma scan Cs-137

Including gamma scan Cs-137 Dissolution volume $=100 \mathrm{~mL}$

Dissolution volume $=100 \mathrm{~mL}$

Free-OH and carbonate

Free-OH and carbonate
Including gamma scan Cs-137

Including gamma scan Cs-137 Dissolution volume $=100 \mathrm{~mL}$

Dissolution volume $=100 \mathrm{~mL}$

Free-OH and carbonate

Free-OH and carbonate

Including gamma scan Cs-137

Including gamma scan Cs-137 Dissolution volume $=100 \mathrm{~mL}$

Dissolution volume $=100 \mathrm{~mL}$

Free-OH and carbonate

Free-OH and carbonate

+ With the exception of samples for warm acid strike all other samples were diluted before taking them out of the shielded cells for analyses. Warm acid strike samples were digested in the shielded cell, diluted and brought out. 